\title{
Parasitic zoonoses associated with dogs and cats: a survey of Portuguese pet owners' awareness and deworming practices
}

André Pereira ${ }^{1}$, Ângela Martins ${ }^{2}$, Hugo Brancal ${ }^{3,4,5}$, Hugo Vilhena $^{6,7,8}$, Pedro Silva $^{9}$, Paulo Pimenta ${ }^{10}$, Duarte Diz-Lopes ${ }^{11}$, Nuno Neves ${ }^{12}$, Mónica Coimbra ${ }^{13}$, Ana Catarina Alves ${ }^{14}$, Luís Cardoso ${ }^{6,15}$ and Carla Maia ${ }^{14^{*}}$

\begin{abstract}
Background: Parasitic diseases of companion animals comprise a group of globally distributed and rapidly spreading illnesses that are caused by a wide range of arthropods, helminths and protozoa. In addition to their veterinary importance, many of these parasites can also affect the human population, due to their zoonotic potential. The aim of the present work was to evaluate the knowledge of Portuguese pet owners regarding the zoonotic potential of parasites that dogs and cats can harbour, most common drugs, frequency of use and reasons for endo- and ectoparasite control.

Methods: Seventy hundred and fifty multiple-choice questionnaires designed to obtain data knowledge about the meaning of zoonosis, knowledge about parasitic diseases and perception regarding their zoonotic potential, as well as the drugs, frequency and reason for deworming their animals were delivered to dog and/or cat owners from non-rural (i.e. urban or semi-urban) and rural parishes who attended veterinary medical centres from continental Portugal.

Results: A total of 536 (71.5\%) questionnaires were retrieved. Two hundred and ninety five (56.5\%) responders had heard of zoonosis/zoonoses, but only 184 (35.2 \%) knew their meaning. Tick fever, mange, leishmaniosis and ascaridiosis/roundworms were the parasitic diseases from pets most frequently identified. The number of owners who recognized the different parasitoses, who stated to have heard about zoonoses and who were aware of the potential transmission of parasites from animals to humans was significantly higher in those with intermediate (i.e. $\geq 9$ and $\leq 12$ years of schooling) and/or higher academic degree (i.e. licentiate, master's and/or doctorate degrees). The combinations of febantel-pyrantel-praziquantel (23.5\%) and milbemycin-praziquantel (34.5\%) were the most widely endoparasitic drugs used in dogs and in cats, respectively. The most common ectoparasiticide used in dogs was a combination of imidacloprid-permethrin (33.4\%), while in cats it was imidacloprid (26.3\%) followed by fipronil (25.4\%). The most used treatment schedule against internal and external parasites in dogs and cats was an administration every three months and the main reason to do it was as a prophylactic purpose. (Continued on next page)
\end{abstract}

\footnotetext{
*Correspondence: carlamaia@ihmt.unl.pt

${ }^{14}$ Global Health and Tropical Medicine, Medical Parasitology Unit, Instituto de Higiene e Medicina Tropical, Universidade Nova de Lisboa, Lisbon, Portugal Full list of author information is available at the end of the article
} 
(Continued from previous page)

Conclusions: The majority of Portuguese owners that attended veterinarian clinics use endoparasiticides and ectoparasiticides in/on their pets as a prophylactic measure, although in many cases not in the correct schedule of treatment. In addition, most of them are not aware of the possible transmission of parasites from their dogs and cats to themselves, a fact which highlights the important role of veterinarians in the continuous implementation of effective control measures to reduce the risk of parasitic infections in both humans and companion animals.

Keywords: Owner awareness, Dogs, Cats, Endoparasites, Ectoparasites, Zoonoses, Portugal

\section{Background}

Parasitic diseases caused by a wide range of arthropods, helminths and protozoans can cause serious, even lifethreatening clinical conditions in dogs and cats, with a number of them also affecting the human population, due to their zoonotic potential, a situation that requires a One Health approach.

Multiple methods and routes of transmission of parasites from domestic carnivores to humans are known. These include transmission via food containing parasite stages (e.g. Toxoplasma gondii and Toxocara spp.), via water (e.g. Giardia duodenalis and Cryptosporidium parvum), via direct contact (e.g. Sarcoptes scabiei) or percutaneously (e.g. Ancylostoma spp.), as well as through one or more vector arthropods (e.g. Leishmania spp. and Dirofilaria spp.).

Taking into account that dogs and cats in Europe are frequently infected/infested with a wide range of endoand ectoparasites, including some vector-borne parasites [1-3], the European Scientific Counsel Companion Animal Parasites (ESCCAP; http://www.esccap.org/) has elaborated guidelines for the treatment and control of companion animal parasites, with the aim of protecting not only the health of pets but also the health of the public by reducing the risk of zoonotic parasite transmission. However, awareness of these guidelines and/or the perception of the zoonotic potential of some parasites by pet owners as well as by veterinarians seems to be limited/poor [4-7].

In Portugal, parasitic infections with intestinal helminths (Ancylostoma spp., Dipylidium caninum and Toxocara spp.) and protozoans (G. duodenalis and T. gondii), as well as fruit fly-borne (Thelazia callipaeda), nematocera insect-borne (Dirofilaria immitis, Dirofilaria repens, Leishmania infantum, Onchocerca lupi) and tickborne pathogens (e.g. Rickettsia conorii) of zoonotic concern have been reported in domestic and stray dogs and/ or cats [1, 8-21]. In addition, human cases of cryptosporidiosis, giardiosis, leishmaniosis, Mediterranean spotted fever (aka tick fever), toxocarosis and toxoplasmosis have also been recorded in the country [12, 2226].

As information regarding parasite knowledge and control practices in Portugal is limited to only one study made in a referral animal hospital in Lisbon [7], the aim of the present study was to evaluate the knowledge of pet owners from all the five continental Portuguese regions regarding the zoonotic potential of parasites that dogs and cats can harbour as well as the common drugs, frequency and reasons of deworming.

\section{Methods}

Animals and samples

From October to December 2015, 750 multiple-choice questionnaires were delivered to dog and/or cat owners from non-rural (i.e. urban or semi-urban; with $\geq 2000$ habitants) and rural (i.e. with $<2000$ habitants) parishes who attended veterinary medical centres from the five continental Portuguese NUTS II (Nomenclature of Units for Territorial Statistics): North, Centre, Alentejo, Lisbon and the Algarve.

The questionnaire was designed in order to obtain the following data: knowledge about the meaning of zoonosis/zoonoses, knowledge about parasitic diseases (i.e. ancylostomatosis, ascaridiosis/roundworms, cryptosporidiosis, dipylidiosis, dirofilariosis/heartworm disease, giardiosis, hydatidosis, leishmaniosis, mange, onchocercosis, thelaziosis, tick fever and toxoplasmosis), and perception regarding the zoonotic potential of parasites their pets can harbour, most common drugs, frequency of use and reason for endo- and ectoparasite control in their pets (Additional file 1, Figure S1).

The commercial names of the different endoparasiticides and ectoparasitices were used in the questionnaire; however, since some of the products share the same active ingredient or association of active ingredients, in the Results and Discussion sections the specific name of each compound (i.e. active ingredient) was used.

\section{Statistical analysis}

Whenever appropriate, the Chi-square and Fisher's exact tests were used to compare proportions. Pairwise comparisons between categories of the same independent variable incorporated Bonferroni's correction. A $P$-value $<0.05$ was considered as statistically significant. Analyses were performed with SPSS $^{\oplus} 21$ software for Windows and with StatLib. 


\section{Results}

A total of 536 (71.5\%) questionnaires were obtained (141 from North, 132 from Centre, 108 from Lisbon, 118 from Alentejo and 37 from the Algarve), with $56.2 \%(294 / 523)$ from dog owners, $14.1 \%$ (74/523) from cat owners and $29.6 \%(155 / 523)$ from responders who had dog and cat as pets. Thirteen responders did not provide information on the pet they owned.

\section{Knowledge of pet owners about parasitic diseases and awareness of their zoonotic potential}

Two hundred and ninety five $(56.5 \%)$ of the 522 responders had heard of zoonosis/zoonoses, but only $35.2 \%(184 / 522)$ knew its meaning (Table 1). The number of owners that stated to have heard about zoonosis and were aware of the potential transmission of parasites from animals to humans was significantly higher in

Table 1 Knowledge of the word "zoonosis" and awareness of its meaning by pet owners according to parish of residence, educational qualification, gender, presence of young children in the family and age

\begin{tabular}{|c|c|c|}
\hline \multirow[t]{2}{*}{ Variable/category } & \multicolumn{2}{|c|}{ Percentage $(n)$ of positive responses } \\
\hline & $\begin{array}{l}\text { Zoonoses - } \\
\text { has heard of }\end{array}$ & $\begin{array}{l}\text { Zoonoses - } \\
\text { understands }\end{array}$ \\
\hline Gender & $P=0.271$ & $P=0.081$ \\
\hline Female & $58.5(193)$ & $38.2(126)$ \\
\hline Male & $26.6(102)$ & $30.2(58)$ \\
\hline Total & $56.5(295)$ & $35.2(184)$ \\
\hline Age (years) & $P=0.010$ & $P=0.016$ \\
\hline$\leq 18$ & $1.0(1)^{\mathrm{a}}$ & $0(0)^{\mathrm{b}}$ \\
\hline $19-64$ & $57.6(279)^{\mathrm{a}}$ & $36.8(178)^{\mathrm{b}}$ \\
\hline$\geq 65$ & $53.6(15)$ & $3.3(6)$ \\
\hline Total & $56.5(295)$ & $35.2(184)$ \\
\hline Parish & $P=0.232$ & $P=0.094$ \\
\hline Rural & $52.4(89)$ & $30.0(51)$ \\
\hline Non-rural & $58.3(203)$ & $37.9(132)$ \\
\hline Total & $56.4(292)$ & $35.3(183)$ \\
\hline Schooling (degree) & $P<0.001$ & $P<0.001$ \\
\hline Basic * & $27.3(12)^{c}$ & $11.4(5)^{\mathrm{e}, f}$ \\
\hline Intermediate ${ }^{* *}$ & $44.8(78)^{d}$ & $18.4(32)^{\mathrm{e}, \mathrm{g}}$ \\
\hline Academic ${ }^{* *}$ & $66.4(188)^{c, d}$ & $46.3(131)^{f, g}$ \\
\hline Total & $55.5(278)$ & $33.5(168)$ \\
\hline Presence of young members & $P=0.811$ & $P=0.110$ \\
\hline Yes & $57.8(74)$ & $41.4(53)$ \\
\hline No & $56.1(221)$ & $33.2(131)$ \\
\hline Total & $56.6(295)$ & $64.8(238)$ \\
\hline
\end{tabular}

${ }^{*}<9$ years of schooling; ${ }^{* *} \geq 9$ and $\leq 12$ years of schooling; ${ }^{* *}$ licentiate, master's and/ or doctorate degrees. Bonferroni correction (i.e. multiplying each $P$-value by 3 ) has been incorporated between categories: ${ }^{\mathrm{a}} P=0.003 ;{ }^{\mathrm{b}} P=0.048$; ${ }^{\mathrm{c}} P<0.001 ;{ }^{\mathrm{d}} P<0.001 ;{ }^{\mathrm{e}} P=1.0 ;{ }^{\mathrm{f}} P<0.001 ;{ }^{9} P<0.001$. Only statistically significant differences are shown adults (i.e. $>18$ and $<65$ years old) than in young people (i.e. $\leq 18$ years old) and in owners with intermediate (i.e. $\geq 9$ and $\leq 12$ years of schooling) and higher academic degree (i.e. licentiate, master's and/ or doctorate degrees) than in the ones with a basic degree (i.e. $<9$ years of schooling). There were no differences regarding having heard about and knowing the meaning of zoonosis and the gender, the presence of young members and the place where the responders lived (non-rural or rural parishes).

Regarding the recognition of parasitic diseases from pets, the most frequently identified were tick fever, mange, leishmaniosis and ascaridiosis/roudworms (Table 2). There was a significant difference between the percentage of owners that identified dirofilariosis and toxoplasmosis, hydatidosis and dirofilariosis, and giardiosis and hydatidosis as parasitic diseases of companion animals (Table 2). Less than $15 \%$ of the responders identified dipylidiosis, cryptosporidiosis, ancylostomosis, onchocercosis and thelaziosis as parasitic diseases of dogs and cats (Table 2).

Furthermore, leishmaniosis was recognised by a significantly high number of owners that lived in non-rural parishes than the ones that lived in rural areas (Table 3). Identification of cryptosporidiosis, giardiosis, hydatidosis, leishmaniosis, mange and toxoplasmosis was significantly higher in the owners with an academic degree than in the responders with basic and intermediate educational qualifications, while the recognition of ancylostomosis, onchocercosis and thelaziosis was significantly lower in the responders with an intermediate degree than in the ones with academic qualifications.

Table 2 Identification of parasitic diseases of dogs and cats by the responders

\begin{tabular}{lll}
\hline Disease & $\begin{array}{l}\text { Awareness/ } \\
\text { respondents }(n)\end{array}$ & Frequency (\%) \\
\hline Tick fever & $524 / 531$ & 98.7 \\
Mange & $519 / 531$ & 97.7 \\
Leishmaniosis & $484 / 530$ & 91.3 \\
Ascaridiosis/roundworms & $481 / 531$ & 90.6 \\
Toxoplasmosis & $369 / 531$ & $69.5^{\mathrm{a}}$ \\
Dirofilariosis/heartworm disease & $235 / 478$ & $49.2^{\mathrm{a}}$ \\
Hydatidosis & $210 / 530$ & $39.6^{\mathrm{a}}$ \\
Giardiosis & $131 / 531$ & $24.7^{\mathrm{a}}$ \\
Dipylidiosis & $74 / 508$ & 14.6 \\
Cryptosporidiosis & $70 / 530$ & 13.2 \\
Ancylostomatosis & $69 / 531$ & 13.0 \\
Onchocercosis & $65 / 530$ & 12.3 \\
Thelaziosis & $58 / 531$ & 10.9 \\
\hline
\end{tabular}

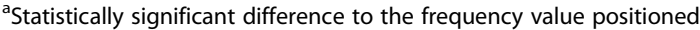
immediately above 
Table 3 Identification of common parasitic diseases by owners of dogs and cats

\begin{tabular}{|c|c|c|c|c|c|c|c|c|c|c|c|c|c|}
\hline \multirow{2}{*}{$\begin{array}{l}\text { Variable/ } \\
\text { category }\end{array}$} & \multicolumn{13}{|c|}{ Percentage $(n)$ of positive responses - "Have you ever heard of?" } \\
\hline & Ancylostomatosis & Ascaridiosis & Cryptosporidiosis & Dipylidiosis & Dirofilariosis & $\begin{array}{l}\text { Tick } \\
\text { fever }\end{array}$ & Giardiosis & Hydatidosis & Leishmaniosis & Onchocercosis & Mange & Thelaziosis & Toxoplasmosis \\
\hline Parish & $P=1.0$ & $P=0.816$ & $P=0.610$ & $P=0.652$ & $P=0.911$ & $P=0.902$ & $P=1.0$ & $P=0.945$ & $P=0.003$ & $P=0.954$ & $P=0.747$ & $P=0.245$ & $P=0.969$ \\
\hline Rural & $12.9(23)$ & $89.9(160)$ & $11.9(21)$ & $13.3(23)$ & $48.5(82)$ & $\begin{array}{l}98.3 \\
(175)\end{array}$ & $24.7(44)$ & $40.1(71)$ & $85.9(152)$ & $11.9(21)$ & $\begin{array}{l}98.3 \\
(175)\end{array}$ & $8.4(15)$ & $69.1(123)$ \\
\hline Non-rural & $13.0(46)$ & 90.9 (321) & $13.9(49)$ & $15.2(51)$ & 49.5 (153) & $\begin{array}{l}98.9 \\
(349)\end{array}$ & $24.6(87)$ & 39.4 (139) & 94.1 (332) & $12.5(44)$ & $\begin{array}{l}97.5 \\
(344)\end{array}$ & $12.2(43)$ & $69.7(246)$ \\
\hline Total & $13.0(69)$ & $90.6(481)$ & $13.2(70)$ & $14.6(74)$ & $49.2(235)$ & $\begin{array}{l}98.7 \\
(524)\end{array}$ & $\begin{array}{l}24.7 \\
(131)\end{array}$ & $39.6(210)$ & 91.3 (484) & $12.3(65)$ & $\begin{array}{l}97.7 \\
(519)\end{array}$ & $10.9(58)$ & 69.5 (369) \\
\hline $\begin{array}{l}\text { Schooling } \\
\text { (degree) }\end{array}$ & $P<0.001$ & $P=0.076$ & $P<0.001$ & $P=0.624$ & $P=0.242$ & $P=0.225$ & $P<0.001$ & $P<0.001$ & $P<0.001$ & $P<0.001$ & $\begin{array}{l}P= \\
0.040^{*}\end{array}$ & $P<0.001$ & $P<0.001$ \\
\hline Basic & $10.4(5)$ & $89.6(43)$ & $4.2(2)^{b}$ & $17.0(8)$ & $37.8(17)$ & $97.9(47)$ & $14.6(7)^{d}$ & $22.9(11)^{f}$ & $70.8(34)^{h, i}$ & $4.2(2)$ & $95.8(46)$ & $10.4(5)$ & $43.8(21)^{\mathrm{m}}$ \\
\hline Intermediate & $3.3(6)^{\mathrm{a}}$ & $87.2(157)$ & $3.9(7)^{c}$ & $15.8(27)$ & $50.6(81)$ & $\begin{array}{l}100 \\
(180)\end{array}$ & $12.8(23)^{e}$ & $28.5(51)^{9}$ & $89.4(160)^{\mathrm{h}, j}$ & $7.3(13)^{k}$ & $\begin{array}{l}96.1 \\
(173)\end{array}$ & $2.2(5)^{1}$ & $57.8(104)^{n}$ \\
\hline Academic & $20.2(58)^{a}$ & 93.4 (268) & $21.7(62)^{b, c}$ & $13.0(36)$ & $51.2(132)$ & $\begin{array}{l}99.3 \\
(285)\end{array}$ & $\begin{array}{l}34.5 \\
(99)^{\mathrm{d}, \mathrm{e}}\end{array}$ & $\begin{array}{l}50.5 \\
(145)^{f, g}\end{array}$ & $95.8(275)^{1, j}$ & $18.5(53)^{k}$ & $\begin{array}{l}99.3 \\
(285)\end{array}$ & $17.1(49)^{\prime}$ & $82.6(237)^{m, n}$ \\
\hline Total & $13.4(69)$ & 90.9 (468) & $13.8(71)$ & $14.4(71)$ & 49.7 (230) & $\begin{array}{l}99.4 \\
(512)\end{array}$ & $\begin{array}{l}25.0 \\
(129)\end{array}$ & $40.3(207)$ & $91.2(469)$ & $13.2(68)$ & $\begin{array}{l}97.9 \\
(504)\end{array}$ & 11.3 (58) & 70.3 (362) \\
\hline
\end{tabular}

Bonferroni correction (i.e. multiplying each $P$ value by 3 ) has been incorporated between schooling categories, and only statistically significant differences are shown; ${ }^{\mathrm{a}} P<0.001 ;{ }^{\mathrm{b}} P=0.024 ;{ }^{\mathrm{c}} P<0.001 ;{ }^{\mathrm{d}} P=0.030$; ${ }^{\mathrm{e}} P<$ $0.001 ;{ }^{\mathrm{f}} P=0.003 ;{ }^{\mathrm{g}} P<0.001 ;{ }^{\mathrm{h}} P=0.009 ;{ }^{\mathrm{i}} P<0.001 ;{ }^{\mathrm{j}} P=0.036 ;{ }^{\mathrm{k}} P=0.003 ;{ }^{\prime} P<0.001 ;{ }^{\mathrm{m}} P<0.001 ;{ }^{\mathrm{n}} P=0.024 ;{ }^{*}$ Statistically significant difference(s) not confirmed after pairwise comparisons 
The awareness of the zoonotic potential of ascaridiosis, hydatidosis, mange and toxoplasmosis among the responders who had previously heard of them was significantly higher in the owners with an academic degree than in the ones with an intermediate level of education (Table 4).

\section{Endoparasitic and ectoparasitic drugs, frequency and reason for deworming}

At the time of the study (i.e. between October and December 2015), $95.5 \%$ (429/449) of the dogs and $90.7 \%$ $(205 / 226)$ of the cats were being treated with endoparasiticide drugs, while $98.2 \%$ (440/448) of the dogs and $91.7 \%$ $(209 / 228)$ of the cats were treated with ectoparasiticides.

The most widely endoparasitic drug used in dogs $(23.5 \%)$ was a combination of febantel-pyrantelpraziquantel, while in cats $(34.5 \%)$ it was a combination of milbemycin-praziquantel (Table 5). In addition, 17.6 and $22.3 \%$ of the owners did not know the drug they used to deworm their dogs and cats, respectively. Regarding frequency of deworming, $33.7 \%$ of the dog owners dewormed every three months and $27.6 \%$ every four months. Only $6.4 \%$ used endoparasiticides monthly. In a similar manner to the dog owners, $38.2 \%(78 / 204)$ of the cat owners dewormed their cats against internal parasites every three months, and $30.9 \%$ (63/204) every four months. Only $2 \%$ of the cat owners dewormed their animals against internal parasites monthly.

Regarding the use of ectoparasiticides in dogs, the most widely used was a combination of imidaclopridpermethrin (33.4\%), while in cats imidacloprid (26.3\%) followed by fipronil (25.4\%) were the most common ones. Eighteen (2.9 \%) of the dog owners and 18 (7.6\%) of the cat owners did not know the product used against external parasites (Table 5). One cat owner $(0.4 \%)$ used permethrin as ectoparasiticide.

One hundred and twenty-six (29.2\%) out of 431 dog owners treated their animals every three months against ectoparasites, and 124 (28.8 \%) monthly. Thirty (7.0 \%) out of $431 \mathrm{dog}$ owners treated their animals yearly. Regarding cats, 56 (28\%) out of 200 owners treated their animals with ectoparasiticides every three months and $26 \%(52 / 200)$ monthly. Only $19(9.5 \%)$ of the cat owners used ectoparasiticides every four months.

The main reason to use endo- and ectoparasiticides in dogs $(82.1 \%)$ and cats $(83.2 \%)$ was as a prophylactic purpose, while $3.7 \%$ of the dog owners and $3.9 \%$ of the cat owners gave antiparasitic products as a treatment for a previously diagnosed/suspected parasitic infection/infestation. About $13.0 \%$ of dog and $12.5 \%$ of cat owners dewormed their pets following recommendation by the veterinarian, and a minor percentage $(1.2 \%)$ did it for other reasons (e.g. public health concern).

\section{Discussion}

Given the clinical importance of intestinal parasites and vector-borne pathogens affecting pets, their global presence and the zoonotic impact of many of them, public education is crucial for reducing risk exposure in both humans and companion animals [3, 27]. In Portugal intestinal helminths and protozoans, as well as vectorborne parasites, have been reported in domestic and stray dogs and/or cats [8-21, 28-31], with some of them having also been recorded in humans [12, 22-26]. In the present study $56.5 \%$ of the responders had heard of the word "zoonosis" and $35.2 \%$ of them (46.3\% among people with an academic degree), were aware of the possible transmission of parasites from their pets to themselves, which was higher than the $29.8 \%$ obtained in a previous study made in São Paulo state (Brazil) [32] but lower than the 49.2 and $75.0 \%$ obtained from pet owners from northern Italy [6] or from a referral small animal hospital in Lisbon, Portugal [7], respectively. The differences regarding the perception of human health risks due to canine and feline parasites among the Portuguese surveys might be related with the fact that the present one was a written questionnaire without an oral interview that could have potentially helped owners to better express their concept of zoonosis. Furthermore, the current investigation was carried out with pet owners that for several reasons attended veterinary clinics/hospitals outside Lisbon (i.e. the capital city), contrarily to the one performed by Matos et al. [7], which comprised owners that visited a referral hospital in Lisbon for a second opinion/specialist appointment, and that were probably more well informed of the health hazards associated with the ownership of a pet. In the same line of thought, this might be the reason why in the present study adult pet owners and the ones with an intermediate or academic degree were more aware of the potential transmission of parasites from animals to humans. In fact, the low schooling level of owners has been regarded as a risk factor for the occurrence of zoonotic gastrointestinal parasites (Ancylostoma spp., Cryptosporidium spp., G. duodenalis, T. gondii and Toxocara spp.) in dogs [33] and in cats [34].

Tick fever, mange, leishmaniosis and ascaridiosis/roudworms were the parasitic and/or arthropod/vector-borne diseases most frequently identified by the responders to the present survey, a situation that might be related with the high frequency of roundworms $[8,15,16,30]$ and leishmaniosis $[11,13]$ reported in Portuguese dogs and cats, as well as with the association of tick fever (i.e. Mediterranean spotted-fever [35]) and sarcoptic mange with human diseases. The differences between the number of pet owners who identified dirofilariosis, toxoplasmosis, hydatidosis and giardiosis might be related with the geographical region where they lived as well as with 
Table 4 Awareness of the potential zoonotic character of each particular disease among those responders who have previously heard of them

\begin{tabular}{|c|c|c|c|c|c|c|c|c|c|c|c|c|c|}
\hline \multirow{2}{*}{$\begin{array}{l}\text { Variable/ } \\
\text { category }\end{array}$} & \multicolumn{13}{|c|}{ Percentage (n) of positive responses - "Are you aware of the zoonotic character of?" } \\
\hline & Ancylostomatosis & Ascaridiosis & Cryptosporidiosis & Dipylidiosis & Dirofilariosis & $\begin{array}{l}\text { Tick } \\
\text { fever }\end{array}$ & Giardiosis & Hydatidosis & Leishmaniosis & Onchocercosis & Mange & Thelaziosis & Toxoplasmosis \\
\hline Parish & $P=0.100$ & $P=0.157$ & $P=0.739$ & $P=0.377$ & $P=0.918$ & $\begin{array}{l}P= \\
0.872\end{array}$ & $P=1.0$ & $P=0.741$ & $P=0.220$ & $P=0.243$ & $P=0.220$ & $P=0.334$ & $P=0.135$ \\
\hline Rural & $56.5(13)$ & 66.5 (105) & $61.9(13)$ & $52.2(12)$ & $19.8(16)$ & $\begin{array}{l}74.4 \\
(128)\end{array}$ & $60.5(26)$ & $54.9(39)$ & $34.2(51)$ & $33.3(7)$ & $\begin{array}{l}71.7 \\
(124)\end{array}$ & $33.3(5)$ & $64.8(79)$ \\
\hline Non-rural & $32.6(15)$ & $73.2(232)$ & $54.2(26)$ & $38.0(19)$ & $18.2(27)$ & $\begin{array}{l}75.5 \\
(262)\end{array}$ & $61.2(52)$ & $51.4(71)$ & 40.6 (134) & $52.3(23)$ & $\begin{array}{l}77.1 \\
(262)\end{array}$ & $52.4(22)$ & 73.0 (178) \\
\hline Total & $40.6(28)$ & 70.9 (337) & 56.5 (39) & $42.5(31)$ & $18.8(43)$ & $\begin{array}{l}75.1 \\
(390)\end{array}$ & $60.9(78)$ & $52.6(110)$ & 38.6 (185) & $46.2(30)$ & $\begin{array}{l}75.2 \\
(386)\end{array}$ & $47.4(27)$ & $70.2(257)$ \\
\hline $\begin{array}{l}\text { Schooling } \\
\text { (degree) }\end{array}$ & $N D^{*}$ & $P=0.013$ & $N D^{*}$ & $N D^{*}$ & $P=0.109$ & $\begin{array}{l}P= \\
0.963\end{array}$ & $N D^{*}$ & $P=0.022$ & $P=0.083$ & $N D^{*}$ & $P=0.025$ & $N D^{*}$ & $P<0.001$ \\
\hline Basic & 60.9 (3) & $73.2(30)$ & $50.0(1)$ & $50.0(4)$ & $29.4(5)$ & $\begin{array}{l}73.3 \\
(33)\end{array}$ & $66.7(4)$ & $27.3(3)$ & $32.4(11)$ & $50.0(1)$ & $79.5(35)$ & $80.0(4)$ & $66.7(14)$ \\
\hline Intermediate & $16.7(1)$ & $61.3(95)^{\mathrm{a}}$ & $28.6(2)$ & $29.6(8)$ & $23.8(19)$ & $\begin{array}{l}75.3 \\
(134)\end{array}$ & $36.4(8)^{b}$ & $40.0(20)$ & $30.4(48)$ & $7.7(1)^{c}$ & $\begin{array}{l}67.8 \\
(116)^{d}\end{array}$ & $0(0)$ & $52.4(54)^{e}$ \\
\hline Academic & $41.4(24)$ & $74.8(199)^{\mathrm{a}}$ & $59.0(36)$ & $54.3(19)$ & $14.1(18)$ & $\begin{array}{l}74.6 \\
(212)\end{array}$ & $\begin{array}{l}67.3 \\
(66)^{b}\end{array}$ & $57.9(84)$ & $40.8(28)$ & $52.8(28)^{c}$ & $\begin{array}{l}78.8 \\
(223)^{d}\end{array}$ & $47.9(23)$ & $76.6(180)^{\mathrm{e}}$ \\
\hline Total & $40.6(28)$ & 70.1 (324) & 55.7 (39) & $44.4(31)$ & $18.7(42)$ & $\begin{array}{l}74.8 \\
(379)\end{array}$ & $61.9(78)$ & $51.9(107)$ & $36.6(30)$ & $44.1(30)$ & $\begin{array}{l}75.1 \\
(374)\end{array}$ & $47.4(27)$ & $69.1(248)$ \\
\hline
\end{tabular}

Bonferroni correction (i.e. multiplying each $P$-value by 3 ) has been incorporated between schooling categories, and only statistically significant differences are shown; ${ }^{\mathrm{a}} P=0.015 ;{ }^{\mathrm{b}} P=0.042 ;{ }^{\mathrm{C}} P=0.027 ;{ }^{\mathrm{d}} P=0.039 ;{ }^{\mathrm{e}} P<$ 0.001 ; ND not validated; *Statistically significant difference(s) not confirmed after pairwise comparisons 
Table 5 Endoparasiticides and ectoparasiticides used in/on dogs and cats

\begin{tabular}{|c|c|c|}
\hline \multirow[t]{2}{*}{ Product } & \multirow{2}{*}{$\begin{array}{l}\text { Dogs } \\
\text { No. (\%) }\end{array}$} & \multirow{2}{*}{$\begin{array}{l}\text { Cats } \\
\text { No. (\%) }\end{array}$} \\
\hline & & \\
\hline Endoparasiticides & 545 & 220 \\
\hline Emodepside + praziquantel & $41(7.5)$ & $8(3.6)$ \\
\hline Emodepside + toltrazuril & $5(0.9)$ & $0(0)$ \\
\hline $\begin{array}{l}\text { Eprinomectin + fipronil + praziquantel + s- } \\
\text { methoprene }\end{array}$ & $2(0.4)^{a}$ & $9(4.1)$ \\
\hline Epsirantel + pyrantel & $3(0.6)$ & $7(3.2)$ \\
\hline Febantel + praziquantel + pyrantel & $\begin{array}{l}128 \\
(23.5)\end{array}$ & $2(0.9)$ \\
\hline Febantel + pyrantel & $18(3.3)$ & $0(0)$ \\
\hline Fenbendazole & $1(0.2)$ & $2(0.9)$ \\
\hline Fenbendazole + praziquantel & $18(3.3)$ & $0(0)$ \\
\hline Ivermectin & $5(0.9)$ & $0(0)$ \\
\hline Ivermectin + pyrantel & $8(1.5)$ & $0(0)$ \\
\hline Mebendazole & $5(0.9)$ & $1(0.5)$ \\
\hline Moxidectin & $1(0.2)$ & $0(0)$ \\
\hline Mylbemicine + praziquantel & $98(18.0)$ & $\begin{array}{l}76 \\
(34.5)\end{array}$ \\
\hline Niclosamide + oxibendazole & $6(1.1)$ & $3(1.4)$ \\
\hline Nitroscanate & $4(0.7)$ & $0(0)$ \\
\hline Oxibendazole + praziquantel & $4(0.7)$ & $0(0)$ \\
\hline Praziquantel & $23(4.2)$ & $2(0.9)$ \\
\hline Praziquantel + pyrantel & $66(12.1)$ & $\begin{array}{l}45 \\
(20.5)\end{array}$ \\
\hline Pyrantel & $13(2.4)$ & $13(5.9)$ \\
\hline Selamectin & $0(0)$ & $3(1.4)$ \\
\hline Do not know & $96(17.6)$ & $\begin{array}{l}49 \\
(22.3)\end{array}$ \\
\hline Ectoparasiticides & 625 & 236 \\
\hline Afoxalaner & $8(1.3)$ & $0(0)$ \\
\hline Amitraz & $1(0.2)$ & $0(0)$ \\
\hline Deltamethrin & $87(13.9)$ & $0(0)$ \\
\hline Dinotefuran + permethrin + pyriproxyfen & $18(2.9)$ & $0(0)$ \\
\hline Dinotefuran + pyriproxyfen & $0(0)$ & $3(1.3)$ \\
\hline $\begin{array}{l}\text { Eprinomectin + fipronil + praziquantel + s- } \\
\text { methoprene }\end{array}$ & $2(0.3)$ & $17(7.2)$ \\
\hline Fipronil & $63(10.1)$ & $\begin{array}{l}60 \\
(25.4)\end{array}$ \\
\hline Fipronil + permethrin & $11(1.8)$ & $0(0)$ \\
\hline Fipronil + s-methoprene & $28(4.5)$ & $23(9.7)$ \\
\hline Flumethrin + imidacloprid & $39(6.2)$ & $13(5.5)$ \\
\hline Fluralaner & $38(6.1)$ & $0(0)$ \\
\hline Imidacloprid & $36(5.8)$ & $\begin{array}{l}62 \\
(26.3)\end{array}$ \\
\hline Imidacloprid + moxidectin & $13(2.1)$ & $18(7.6)$ \\
\hline Imidacloprid + permethrin & $\begin{array}{l}209 \\
(33.4)\end{array}$ & $0(0)$ \\
\hline
\end{tabular}

Table 5 Endoparasiticides and ectoparasiticides used in/on dogs and cats (Continued)

$\begin{array}{lll}\text { Indoxacarb } & 17(2.7) & 15(6.4) \\ \text { Lufenuron } & 6(1.0) & 0(0) \\ \text { Permethrin } & 24(3.8) & 1(0.4)^{\mathrm{a}} \\ \text { Pyriprole } & 1(0.2) & 0(0) \\ \text { Selamectin } & 6(1.0) & 3(1.3) \\ \text { Spinosad } & 0(0) & 3(1.3) \\ \text { Do not know } & 18(2.9) & 18(7.6)\end{array}$

${ }^{a}$ Although the product is not approved for this species, pet owners have declared to apply it

gender since canine heartworm disease is more common in the Centre and in the South of Portugal [11, 36], most of the reported cases of human hydatidosis are notified from Alentejo [37], giardiosis has been reported in children from Lisbon [24, 38], and toxoplasmosis is mostly associated with pregnancy or women of childbearing age [39]. The fact that less than $15 \%$ of the responders identified ancylostomosis, cryptosporidiosis, dipylidiosis, onchocercosis and thelaziosis as parasitic diseases of the dogs and cats, might be related with the difficulty in observing the first two parasites in the faeces of their pets due to the small size of Ancylostoma spp. adult parasites (contrarily to Toxocara spp.) and Cryptosporidium spp. oocysts, to the misidentification of $D$. caninum with roundworms, and to the fact that the detection of the last two nematodes is relatively recent in Portugal $[40,41]$.

According to the ESCCAP guidelines and depending on the different scenarios (e.g. presence of children or outdoor access), the frequency of treatment against internal parasites should be at least four times per year, at intervals not exceeding three months apart or preferably a monthly treatment, while treatment against ectoparasites should also be done monthly. In the present study, $67.7 \%(285 / 421)$ of the dog owners and $71.1 \%(145 /$ 204 ) of the cat owners treated their pets against endoparasites at every four, three or one months. When a year-round control is not performed (in the present study internal monthly deworming was only performed by $6.4 \%$ of the dog owners and $2 \%$ of the cat owners) veterinarians should inform owners about the importance of regular faecal examinations (monthly or at least quarterly) for evaluating the (re)occurrence of intestinal parasites (www.esccap.org). In the same line, and since only $26 \%$ of the dog owners and $28.8 \%$ of the cat owners monthly treated their pets against ectoparasites, it would also be important to screen companion animals for vector-borne pathogens (e.g. L. infantum and D. immitis) at least once a year, preferably outside the period of vector activity, as this procedure would probably contribute to more detection of established infections. 
The endoparasiticides most commonly used in the dogs (i.e. febantel-pyrantel-praziquantel, and milbemycinpraziquantel) and in the cats (i.e. milbemycinpraziquantel, and pyrantel-praziquantel) from the present study are effective against roundworms, hookworms, tapeworms and heartworms (only the ones containing mylbemycin, against heartworms). Therefore, these pets can be considered protected from these helminths as long as the owners comply with the correct schedule of treatment; however, these drugs are not effective against intestinal protozoa, which is probably the reason why Cystoisospora spp., G. duodenalis and T. gondii infections are quite common in domestic dogs and cats from Portugal $[10,15,16,42,43]$. On the other hand, the reason why vector-borne pathogens are quite frequent in Portuguese domestic dogs and cats $[11,13,17,29,44]$, even when they are treated with effective ectoparasiticide products against vector arthropods (e.g. imidacloprid-permethrin for dogs and imidacloprid and fipronil for cats) is probably related with the low percentage of animals protected yearround or, as referred for anthelminthics, to the lack of compliance for ectoparasiticide application, or in the case of cats to the impossibility to apply pyrethroids (the only repellents effective against sand flies), due to their toxicity to felids.

\section{Conclusions}

The majority of the Portuguese pet owners that attend veterinary clinics administrate endoparasiticides and ectoparasitices to their pets as a prophylatic measure against internal and external parasites, although in many cases not in the correct schedule of treatment. In addition, the present study highlights the important role of veterinarians in providing owners with concise but objective information about the ways of pathogen transmission to their pets and themselves, which can be done for instance through appellative and easy-to-understand flyers, regular newsletters using social networks, and free or low cost workshops of short duration. The increase of owners' awareness about zoonotic and parasitic diseases should also include the implementation of effective control measures to reduce the risk of parasitic infections in both companion animals and humans, which can be done by reminding, via online or short message service, about the importance of faecal microscopic examinations and screening of vector-borne pathogens in a regular basis, as well as through accurate deworming schedules and appropriate life-long actions and regular removal and disposal of faeces to minimize environmental contamination.

\section{Additional file}

Additional file 1: Figure S1. Questionnarie regarding dog and cat owners awareness on parasitic diseases, their zoonotic potential and the endo- and ectoparasiticide products most commonly used, frequency and reason of administration to their pets. (DOCX $82 \mathrm{~kb}$ )

\section{Competing interests}

The authors declare that they have no competing interests.

\section{Authors' contributions}

$A P, A M, H B, H V, P S, P P, D D-L, N N, M C$ and ACA delivered and collected the questionnaries; AP and LC performed data analysis and revised the manuscript. CM planned, designed and supervised the study, and wrote the manuscript. All authors read and approved the final manuscript.

\section{Acknowledgements}

The authors thank FCT for funds to GHTM - UID/Multi/04413/2013 and the cooperation of veterinarians, auxiliary staff and dog and cat owners. The work of C. Maia and L. Cardoso was done under the frame of EurNegVec COST Action TD1303. Publication of this paper has been sponsored by Bayer HealthCare - Animal Health Division in the framework of the 11th CVBD World Forum Symposium.

\section{Author details}

${ }^{1}$ Faculty of Veterinary Medicine, Universidade Lusófona de Humanidades e Tecnologias, Lisboa, Portugal. ${ }^{2}$ Hospital Veterinário da Arrábida, Azeitão, Portugal. ${ }^{3}$ Clínica Veterinária da Covilhã, Covilhã, Portugal. ${ }^{4}$ Faculty of Health Sciences, University of Beira Interior, Covilhã, Portugal. ${ }^{5}$ Agrarian College, Polytechnic Institute of Castelo Branco, Castelo Branco, Portugal. ${ }^{6}$ Animal and Veterinary Research Centre (CECAV), School of Agrarian and Veterinary Sciences, University of Trás-os-Montes e Alto Douro (UTAD), Vila Real, Portugal. ${ }^{7}$ Department of Veterinary Medicine, University School Vasco da Gama, Coimbra, Portugal. ${ }^{8}$ Hospital Veterinário do Baixo Vouga, Águeda, Portugal. ${ }^{9}$ Amivet - Clínica Veterinária, Évora, Portugal. ${ }^{10}$ Hospital Veterinário de Trás-os-Montes, Vila Real, Portugal. ${ }^{11}$ VetSantiago - Clínica Veterinária Dr. Duarte Diz-Lopes, Bragança, Portugal. ${ }^{12}$ Clube Animal - Centro Veterinário, Beja, Portugal. ${ }^{13}$ Clínica Veterinária Porto Seguro, Olhão, Portugal. ${ }^{14} \mathrm{Global}$ Health and Tropical Medicine, Medical Parasitology Unit, Instituto de Higiene e Medicina Tropical, Universidade Nova de Lisboa, Lisbon, Portugal.

${ }^{15}$ Department of Veterinary Sciences, School of Agrarian and Veterinary

Sciences, UTAD, Vila Real, Portugal.

Received: 10 March 2016 Accepted: 25 April 2016

Published online: 10 May 2016

\section{References}

1. Otranto D, Dantas-Torres F, Brianti E, Traversa D, Petrić D, Genchi C, et al. Vector-borne helminths of dogs and humans in Europe. Parasit Vectors. 2013;6:16.

2. Beugnet F, Bourdeau P, Chalvet-Monfray K, Cozma V, Farkas R, Guillot J, et al. Parasites of domestic owned cats in Europe: co-infestations and risk factors. Parasit Vectors. 2014;7:291.

3. Baneth G, Thamsborg SM, Otranto D, Guillot J, Blaga R, Deplazes P, et al. Major parasitic zoonoses associated with dogs and cats in Europe. J Comp Pathol. 2015; doi: 10.1016/j.jcpa.2015.10.179.

4. Bourdeau P, Saridomichelakis MN, Oliveira A, Oliva G, Kotnik T, Gálvez R, et al. Management of canine leishmaniosis in endemic SW European regions: a questionnaire-based multinational survey. Parasit Vectors. 2014;7:110.

5. Genchi C, Bowman D, Drake J. Canine heartworm disease (Dirofilaria immitis) in Western Europe: survey of veterinary awareness and perceptions. Parasit Vectors. 2014;7:206.

6. Zanzani SA, Gazzonis AL, Scarpa P, Berrilli F, Manfredi MT. Intestinal parasites of owned dogs and cats from metropolitan and micropolitan areas: prevalence, zoonotic risks, and pet owner awareness in northern Italy. Biomed Res Int. 2014; 10.1155/2014/696508.

7. Matos M, Alho AM, Owen SP, Nunes T, Madeira de Carvalho L. Parasite control practices and public perception of parasitic diseases: a survey of dog and cat owners. Prev Vet Med. 2015;122:174-80. 
8. Duarte A, Castro I, Pereira da Fonseca IM, Almeida V, Madeira de Carvalho LM, Meireles J, et al. Survey of infectious and parasitic diseases in stray cats at the Lisbon Metropolitan Area, Portugal. J Feline Med Surg. 2010;12:441-6.

9. Alexandre N, Santos AS, Bacellar F, Boinas FJ, Núncio MS, de Sousa R. Detection of Rickettsia conorii strains in Portuguese dogs (Canis familiaris). Ticks Tick Borne Dis. 2011;2:119-22.

10. Ferreira FS, Pereira-Baltasar P, Parreira R, Padre L, Vilhena M, Távora Tavira L, et al. Intestinal parasites in dogs and cats from the district of Évora, Portugal. Vet Parasitol. 2011;179:242-5.

11. Cardoso L, Mendão C, Madeira de Carvalho L. Prevalence of Dirofilaria immitis, Ehrlichia canis, Borrelia burgdorferi sensu lato, Anaplasma spp. and Leishmania infantum in apparently healthy and CVBD-suspect dogs in Portugal - a national serological stud. Parasit Vectors. 2012;5:62.

12. Lopes AP, Dubey JP, Dardé ML, Cardoso L. Epidemiological review of Toxoplasma gondii infection in humans and animals in Portugal. Parasitology. 2014;141:1699-708.

13. Maia C, Ramos C, Coimbra M, Bastos F, Martins A, Pinto P, et al. Bacterial and protozoal agents of feline vector-borne diseases in domestic and stray cats from southern Portugal. Parasit Vectors. 2014;7:115

14. Maia C, Catarino AL, Almeida B, Ramos C, Campino L, Cardoso L. Emergence of Thelazia callipaeda infection in dogs and cats from east-central Portugal. Transbound Emerg Dis. 2014; doi:10.1111/tbed.12284.

15. Mateus TL, Castro A, Ribeiro JN, Vieira-Pinto M. Multiple zoonotic parasites identified in dog feces collected in Ponte de Lima, Portugal - a potential threat to human health. Int J Environ Res Public Health. 2014;11:9050-67.

16. Neves D, Lobo L, Simões PB, Cardoso L. Frequency of intestinal parasites in pet dogs from an urban area (Greater Oporto, northern Portugal). Vet Parasitol. 2014:200:295-8.

17. Maia C, Ramos C, Coimbra M, Cardoso L, Campino L. Prevalence of Dirofilaria immitis antigen and antibodies to Leishmania infantum in cats from southern Portugal. Parasitol Int. 2015;64:154-6.

18. Maia C, Almeida B, Coimbra M, Fernandes MC, Cristóvão JM, Ramos C, et al. Bacterial and protozoal agents of canine vector-borne diseases in the blood of domestic and stray dogs from southern Portugal. Parasit Vectors. 2015;8:759.

19. Maia C, Coimbra M, Ramos C, Cristóvão JM, Cardoso L, Campino L. Serological investigation of Leishmania infantum, Dirofilaria immitis and Angiostrongylus vasorum in dogs from southern Portugal. Parasit Vectors. 2015;8:152.

20. Maia C, Lorentz S, Cardoso L, Otranto D, Naucke T. Detection of Dirofilaria repens microfilariae in a dog from Portugal. Parasitol Res. 2016;115:441-3.

21. Maia C, Annoscia G, Latrofa MS, Pereira A, Giannelli A, Pedroso L, et al. Onchocerca lupi nematode in cat, Portugal. Emerg Infect Dis. 2015;21:2252-3.

22. Matos O, Alves M, Xiao L, Cama V, Antunes F. Cryptosporidium felis and C. meleagridis in persons with HIV, Portugal. Emerg Infect Dis. 2004;10:2256-7.

23. Campino L, Maia C. Epidemiology of leishmaniases in Portugal. Acta Med Port. 2010;23:859-64.

24. Júlio C, Vilares A, Oleastro M, Ferreira I, Gomes S, Monteiro L, et al. Prevalence and risk factors for Giardia duodenalis infection among children: a case study in Portugal. Parasit Vectors. 2012;5:22.

25. Marques A, Rodrigues A, Belo S, Guedes ME. Unusual panuveitis in a child: toxocariasis associated with ocular myiasis. BMJ Case Rep. 2014; doi: 10 1136/bcr-2014-204475

26. Crespo P, Seixas D, Marques N, Oliveira J, da Cunha S, Meliço-Silvestre A Mediterranean spotted fever: case series of 24 years (1989-2012). SpringerPlus. 2015:4:272

27. Traversa D. Pet roundworms and hookworms: a continuing need for global worming. Parasit Vectors. 2012;5:91.

28. Otranto D, Dantas-Torres F, Giannelli A, Latrofa MS, Papadopoulos E, Cardoso L, et al. Zoonotic Onchocerca lupi infection in dogs, Greece and Portugal, 2011-2012. Emerg Infect Dis. 2013;19:2000-3.

29. Vilhena H, Martinez-Díaz VL, Cardoso L, Vieira L, Altet L, Francino O, et al. Feline vector-borne pathogens in the north and centre of Portugal. Parasit Vectors. 2013;15:6-99.

30. Waap H, Gomes J, Nunes T. Parasite communities in stray cat populations from Lisbon, Portugal. J Helminthol. 2013;88:389-95.

31. Cardoso AS, Costa IM, Fiqueiredo C, Castro A, Conceição MA. The occurrence of zoonotic parasites in rural dog populations from northern Portugal. J Helminthol. 2014;88:203-9.

32. Katagiri S, Oliveira-Sequeira TC. Prevalence of dog intestinal parasites and risk perception of zoonotic infection by dog owners in São Paulo State, Brazil. Zoonoses Public Health. 2008;55:406-13.
33. Balassiano B, Campos M, Menezes R, Pereira M. Factors associated with gastrointestinal parasite infection in dogs in Rio de Janeiro, Brazil. Prev Vet Med. 2009;91:234-40.

34. Pivoto F, Lopes L, Vogel F, Botton S, Sangioni L. Ocorrência de parasitos gastrointestinais e fatores de risco de parasitismo em gatos domésticos urbanos de Santa Maria, RS, Brasil. Ciênc Rural. 2013;43:1453-8.

35. Directorate-General of Health. 2014. [https://www.dgs.pt/estatisticas-desaude/estatisticas-de-saude/publicacoes/doencas-de-declaracao-obrigatoria2011-2014-volume-i2.aspx]. Accessed on 9 March 2016.

36. Alho AM, Landum M, Ferreira C, Meireles J, Gonçalves L, de Carvalho LM, et al. Prevalence and seasonal variations of canine dirofilariosis in Portugal. Vet Parasitol. 2014;206:99-105.

37. Directorate-General of Health. 2008. [https://www.dgs.pt/estatisticas-desaude/estatisticas-de-saude/publicacoes/doencas-de-declaracao-obrigatoria2004-2008.aspx]. Accessed on 9 March 2016.

38. Ferreira FS, Machado Sá da Bandeira RA, Constantino CA, da Fonseca AM, Gomes J, Rodrigues RM, et al. Molecular and clinical characterization of Giardia duodenalis infection in preschool children from Lisbon, Portugal. J Parasitol Res. 2013;2013:1-6.

39. Lopes AP, Dubey JP, Moutinho O, Gargaté MJ, Vilares A, Rodrigues M, et al. Seroepidemiology of Toxoplasma gondii infection in women from the North of Portugal in their childbearing years. Epidemiol Infect. 2012;140:872-7.

40. Faísca P, Morales-Hojas R, Alves M, Gomes J, Botelho M, Melo M, et al. A case of canine ocular onchocercosis in Portugal. Vet Ophthalmol. 2010;13:117-21

41. Vieira L, Rodrigues FT, Costa A, Diz-Lopes D, Machado J, Coutinho T, et al. First report of canine ocular thelaziosis by Thelazia callipaeda in Portugal. Parasit Vectors. 2012;5:124

42. Lopes AP, Cardoso L, Rodrigues M. Serological survey of Toxoplasma gondii infection in domestic cats from northeastern Portugal. Vet Parasitol. 2008:155:184-9.

43. Lopes AP, Santos H, Neto F, Rodrigues M, Kwok OCH, Dubey JP, et al. Prevalence of antibodies to Toxoplasma gondii in dogs from northeastern Portugal. J Parasitol. 2011;97:418-20.

44. Martínez-Díaz VL, Silvestre-Ferreira AC, Vilhena $H$, Pastor J, Francino O, Altet L. Prevalence and co-infection of haemotropic mycoplasmas in Portuguese cats by real-time polymerase chain reaction. J Feline Med Surg. 2013;15:879-85.

\section{Submit your next manuscript to BioMed Central and we will help you at every step:}

- We accept pre-submission inquiries

- Our selector tool helps you to find the most relevant journal

- We provide round the clock customer support

- Convenient online submission

- Thorough peer review

- Inclusion in PubMed and all major indexing services

- Maximum visibility for your research

Submit your manuscript at www.biomedcentral.com/submit
) Biomed Central 